\title{
MOA Framework and Website Quality as Creator of Attitude and Behavioral Consequences
}

\author{
Whony Rofianto \\ Indonesia Banking School \\ rofianto@ibs.ac.id
}

\begin{abstract}
This study aimed to examine the factors driving the establishment of user satisfaction on the campus website. The study focused on two exogenous constructs, namely website quality as the external aspects and the MOA framework (especially motivation and ability) as the internal aspects for users of the campus website. The study also tried to examine the dual implications of user satisfaction, toward the intention to revisit on one side, also toward attitude and word-of-mouth intention on the campuses itself on the other side. This study was conducted using descriptive research design approach. A total of 210 cross-sectional data collected through an offline and online survey on student sample of state and private universities in the JABODETABEK area. Data analysis and hypothesis testing was executed using Structural Equation Model. The analysis of empirical data indicates a positive impact of website quality on user satisfaction. Furthermore, user satisfaction proven to give positive implications toward revisit intention on the one hand, and the attitude toward the brand on the other side, which in turn encourages word-of-mouth intention. Meanwhile, opposite findings on the effect of the MOA framework on user satisfaction, it gives a new insight that amplifies the urgency of the implementation of campus website by higher education providers.
\end{abstract}

Keywords: MOA, website quality, user satisfaction, revisit intention, word-of-mouth intention.

Penelitian ini ditujukan untuk menelaah faktor penggerak terbentuknya user satisfaction pada layanan website kampus. Penelitian difokuskan pada konstruk eksogen website quality sebagai aspek eksternal and rerangka MOA (khususnya motivation and ability) sebagai aspek internal bagi pengguna website kampus. Penelitian ini juga berupaya meninjau implikasi ganda user satisfaction terhadap intention to revisit serta attitude and word-of-mouth intention atas entitas perguruan tinggi penyelenggara website kampus tersebut. Penelitian dilakukan dengan desain riset deskriptif. Sebanyak 210 data 
cross-sectional dihimpun melalui survei offline and online atas mahasiswa PTN and PTS di daerah JABODETABEK. Analisis data and uji hipotesis dilakukan secara kuantitatif menggunakan Structural Equation Model. Hasil analisis terhadap data empiris yang dihimpun mengindikasikan adanya dampak positif signifikan website quality terhadap user satisfaction. Lebih jauh lagi, user satisfaction terbukti memberikan implikasi positif ganda terhadap revisit intention di satu sisi, serta terhadap attitude toward the brand yang pada akhirnya mendorong word-of-mouth intention di sisi lain. Sementara itu, temuan akan pengaruh motivation and ability terhadap user satisfaction yang berlawanan dengan dugaan semula, justru memberikan penjelasan yang mengamplifikasi adanya urgensi penyelenggaraan website kampus yang baik oleh penyelenggara pendidikan tinggi.

Kata Kunci: MOA, website quality, revisit intention, word-of-mouth intention, higher education marketing.

\section{Introduction}

Nowadays, the development of information technology and communications has happened quickly. This development takes place in both the software and supporting hardware. Support for development on both sides drives to condition of convergence of function and physical form. It leads to a device that can perform many functions and easy to carry by users or often referred to as mobile.

Consumers who have evolved into digital consumers with more demanding characteristic want many things instantly, get more comfortable with internet, and become more vocals (Baker, 2004; Ryan \& Jones, 2012). Regarding this condition, digital communication media such as website and social media becoming more important for a company to communicate with its customers. Company can use website as opening gate for one way or two-way communication mode. Through digital communication media such as social media, communication can take the form as many-to-many (Yadav \& Varadarajan, 2005).

High education industry with tighter competition can certainly adopt marketing strategy similar to a company including utilizing digital communication media to create interaction with modern consumers. This effort can be reached to give better value over competitors to customers. At this context, high education institution can use their website as portal to many information, digital service, as well as interactive communication medium for customers, which are students and all stakeholders.

One expected implication from digital communication media utilization is positive attitude towards brand that pushes intentional behaviour and its behaviour creation. In this context, marketing behaviour refers to loyal behaviour to products or brands. If discussion on digital communication media is focused on the website's form, previous researches 
indicate that website quality is triggering aspect in creating positive behaviour towards brand (Al-Qeisi, Dennis, Alamanos, \& Jayawardhena, 2014). Research on exchange among customers through digital media, motivation, opportunity and ability aspects which is included within MOA framework (Motivation, Opportunity and Ability) is said to have influence to perception on value of the brand and behavioral intention (Gruen, Osmonbekov, \& Czaplewski, 2007).

This research aims to analyze factors that trigger consumer's positive behavior towards brand and its implication to behavioral intention in the context of higher education. Previous research has examined costumer's internal aspect (motivation, opportunity and ability) and customer's external aspect (website quality) separately as triggering factors in creating positive behaviour towards brand. This research is going to analyse the impact of both aspects in creating customers' positive behaviour to a higher educational degree at the same time.

\section{Literature Review}

In the previous research, MOA framework was addressed to explain that process of understanding advertisement stimulus in the mind of consumer can really depend on the level of customer's motivation, opportunity and ability pelanggan that eventually influences customer's behaviour towards brands (Maclnnis \& Jaworski, 1989). The framework is initially submitted in the form of complex hypothetical relations to explain process of information to marketer's communication signal, delivered through advertisement, can shape customer's behaviour to advertised brands. Nevertheless, during the process, others researchers such as Gruen et al., 2007 simplified the three constructs as equal constructs that affect the formation of customer's behaviour.

Motivation can be seen as a force that can propel someone to achieve their goal which it will be manifested further in the form of consumer's attitude, decision, or behaviour (Maclnnis \& Jaworski, 1989). On the other hand, opportunity described as the degree of conduciveness environment around someone to achieve certain desired result (Gruen et al., 2007). While ability portrays number of resources that someone has to realize their goals (Hoyer \& Maclnnis, 2008).

In the context of retail, website is an analogy of physical realm in the conventional retail., it means that website has important role in attracting and maintaining customers (Kim \& Niehm, 2009). The quality of website will determine customer's behaviour on reusing the website including important decision such as transaction on the website. (AlQeisi et al., 2014; Kim \& Niehm, 2009). The quality of website can be spelled out as multi- 
dimensional construction that consists of some dimension such as technical quality, general quality, and interface quality (Al-Qeisi et al., 2014).

Consumer satisfaction is an affective response of consumer to certain products or service in the form of satisfaction or dissatisfaction to the products or service according to evaluation that they do (Oliver, 1999). The evaluation can happen during purchasing or consumer's experience at the moment of using the products or service (Giese \& Cote, 2000). Satisfaction construct is an antecedent on behaviour forming and behavioural intention to certain brands, product, or services (Oliver, 1980).

Attitude toward behaviour is defined as a degree of positive or negative assessment to certain type of behaviour (Icek Ajzen, 1991). According to that basic definition, the analogy can be drawn that attitude to brands or service is a negative or positive assessment of individual to certain brand or service. Furthermore, attitude is one of antecedent of intention to formation that ends on behaviour formation (Icek Ajzen, 1991).

Observation about behavioural intention in the context of marketing is usually connected to loyal behaviour to a brand. Loyal behaviour is usually indicated by revisit behaviour, not easily turned to other brands, willingness to pay the premium price, and positive word-of-mouth (Brakus, Schmitt, \& Zarantonello, 2009; Yoo \& Donthu, 2001). In this research, behavioural intention is reviewed against two interrelated object that is university and university's website. Behavioural intention towards university as a brand entity or service can be reviewed through positive word-of-mouth intention construct. Meanwhile, behavioural intention towards university's website can be reviewed with intention to revisit the construct.

\section{Hypothesis Development}

High degree of motivation, opportunity and ability enable better process of brand communication stimulus (Maclnnis \& Jaworski, 1989). Consumer's response, especially affectively in choosing, purchasing or consumption is often called the terminology customer satisfaction in the marketing literature (Giese \& Cote, 2000). In this research, consumers are campus' website user. Therefore, in this research specific terminology, user satisfaction, is chosen to label customer satisfaction construct more specifically.

University students as research object come from $Y$ generation, which is known to have tendency to be digital native with characteristic of being capable to use information technology in its daily activity. Nevertheless, previous research indicated that there are still more variation in the capability and frequency degree in using the information technology (Selwyn, 2009). Therefore, researcher assessed that the use of ability dimension to represent MOA construct is still relevant. Meanwhile, in the homogenous sample, university student with relatively homogenous degree and type of activity, researcher 
assessed opportunity construct as one dimension from MOA concept becomes irrelevant. Thus, researcher only brings motivation and ability as MOA dimension in this research. Following above explanation, first hypothesis of this research is as follows:

$\mathrm{H}_{1}$ : MOA has a positive effect on user satisfaction

High quality websites can increase expectation on services from the institution behind the website, and it may create positive experience about the website and website's host. (Al-Qeisi et al., 2014). Expectation and this positive experience can shape consumer's positive behaviour towards the services (Ajzen \& Fishbein, 1980). The behavior can be in the form of affective response to the particular service, at this point university's website. User's affective response to the use of service is one example of user satisfaction reflection (Giese \& Cote, 2000). According to that argumentation, it can be said that the better website of quality of university, the higher user satisfaction towards service of university website.

$\mathrm{H}_{2}$ : Website quality has positive effect on user satisfaction

Customer satisfaction is seen as antecedent of behavior and behavioral intention towards one brand, product, or service. Furthermore, correlation between satisfaction and attitude shows higher value compared to correlation between satisfaction and behavioral intention (Oliver, 1980). Based on that fact, it is expected that user satisfaction will create higher positive attitude towards brand of certain service. In this case, website can be perceived as one of university's service elements.

$\mathrm{H}_{3}$ : User satisfaction has positive effect on attitude toward the brand

Positive attitude toward certain thing is an antecedent of the behavioural intention forming which can eventually be materialized into actual behaviour (Icek Ajzen, 1991). Based on this argumentation, it can be proposed that any positive behaviour towards service can have positive impact on the formation of behavioural intention, in this case, to spread positive word of mouth.

$\mathrm{H}_{4}$ : Attitude toward the brand has positive effect on word-of-mouth intention

At the beginning, satisfaction was judged to have stronger correlation with attitude in comparison to correlation with behavioral intention (Oliver, 1980). Nevertheless, there are more research in various context of discussion with antecedent addition and wider consequences that examine direct impact of satisfaction toward behavioral intention, especially loyal behavior intention. (Brakus et al., 2009; Kuppelwieser \& Sarstedt, 2014). More specifically, this research focuses on observation on intention to revisit as often used behavioral intention construct in related research about digital service. (Brunner-Sperdin, Scholl-Grissemann, \& Stokburger-Sauer, 2014; Jung, Kim, \& Kim, 2014).

$\mathrm{H}_{5}$ : User satisfaction has positive effect on intention to revisit 
According to framework of thinking that has been explained before, the model and research's hypothesis can be illustrated as follows:

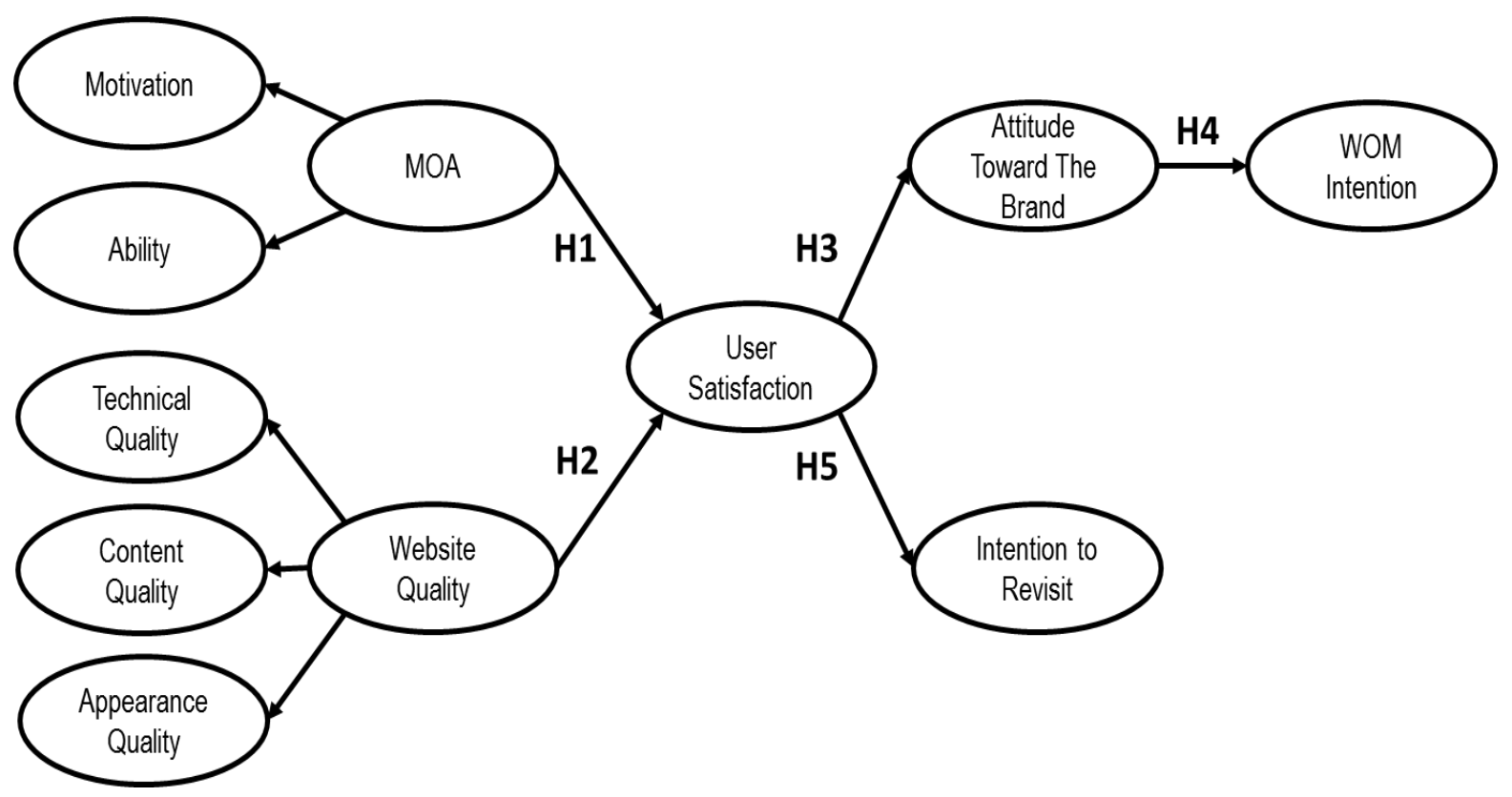

Figure 1. Research Model

\section{Methods}

This research is limited to public and private universities in JABODETABEK because they can represent universities with relatively good website. The chosen analytical unit as data extraction entity in this research is university student in JABODETABEK. Therefore, population of this research is active student of university in JABODETABEK area. Like most researches, it is not possible to include all member of population in the process of data collection. Thus, sample as part of population is chosen to represent population in this research. (Cooper \& Schindler, 2013). In this case, the sample is representative of active students in JABODETABEK who are selected as research's respondents.

This research use descriptive research design that aims to describe population characteristic or relations among research variables (Cooper \& Schindler, 2011). This research only takes sample at one time and it also mean this research uses cross-sectional design, which is often used in descriptive research over longitudinal design (Maholtra, 2007). Hypothetical examination will base on analysis on primary data, which is specifically collected for one research's purpose (Aaker, Kumar, Day \& Leone, 2011). The data is collected from survey, a method to gain respondent's information through questionnaire or interview (Malhotra, 2007). Survey is a suitable method that researchers can use when they want to measure attitude, activity, opinion, belief of respondents (Christensen, Johnson \& Turner, 2011). 
This research collects the data through survey. This research uses combination of offline questionnaire and online questionnaire as measurement instrument. Data collection execution through offline and online questionnaire is self-administered which means respondents are free to answer question inside the questionnaire list whenever without researcher's intervention (Cooper \& Schindler, 2011) unless they need to have additional explanation, especially in offline questionnaire. By involving online survey, the used sampling technique is convenience sampling (Zikmund, Babin, Carr, \& Griffin, 2010) considering there is a voluntary characteristic in choosing the respondents. This research involves 35 indicators in data collection. In the research with factor analysis element, the number of respondents should have been between 5 to 10 times higher than number of indicators (Hair, Black, Babin, \& Anderson, 2010). Following that consideration, this research is trying to collect data from 210 respondents, or six times higher than number of research indicators.

Measuring tools of this research adopts some previous researches by translating and adjusting the sentence into the context of Indonesia. MOA measuring tool adopts result of research (Gruen et al., 2007). Website quality measuring tools adopt research. User satisfaction measuring tool adopts research (Pontevia, N'Goala, \& Poncin, 2013). Revisit intention measuring tool adopts (Kim \& Niehm, 2009). Attitude toward the brand measuring tool is adopted from (Spears \& Singh, 2004). Meanwhile, WOM intention is adopted from research (Hanzaee \& Alinejad, 2012). List of measuring tools which this researches use is outlined more specific at Table 1.

Table 1. Operational Variables

\begin{tabular}{|l|l|}
\hline \multicolumn{1}{|c|}{ Variables } & \multicolumn{1}{c|}{ Measuring Tools } \\
\hline $\begin{array}{l}\text { Motivation } \\
\text { (MOT) }\end{array}$ & $\begin{array}{l}\text { MOT1. I feel it is necessary to dig the latest information from my university's } \\
\text { website } \\
\text { MOT2. I am very interested with new information in my university's website } \\
\text { MOT3. I am so excited to explore my university's website }\end{array}$ \\
\hline $\begin{array}{l}\text { Ability } \\
\text { (ABI) }\end{array}$ & $\begin{array}{l}\text { ABI1. It is easy for me to search for the information that I needed in my } \\
\text { university's website } \\
\text { ABI2. I am quite adept to use all feature that is provided in my university's } \\
\text { website }\end{array}$ \\
$\begin{array}{l}\text { Technical } \\
\text { Quality } \\
\text { (TEC) }\end{array}$ & $\begin{array}{l}\text { TEC1. My university's website has good navigation system } \\
\text { TEC2. My university's website has good search system } \\
\text { TEC3. My university's website has many interactive feature (such as online } \\
\text { form, customer service chat) }\end{array}$ \\
& TEC4. My university's website can be easily accessed \\
\hline
\end{tabular}




\begin{tabular}{|c|c|}
\hline Variables & Measuring Tools \\
\hline & TEC5. My university's website can load fact \\
\hline $\begin{array}{l}\text { Content } \\
\text { Quality } \\
\text { (CON) }\end{array}$ & $\begin{array}{l}\text { CON1 My university's website provides me with many useful information } \\
\text { CON2 My university's website provides various comprehensive information } \\
\text { CON3 My university's website provides clear information } \\
\text { CON4 My university's website always has updated information } \\
\text { CON5 My university's website provides accurate information }\end{array}$ \\
\hline $\begin{array}{l}\text { Appereance } \\
\text { Quality } \\
\text { (APP) }\end{array}$ & $\begin{array}{l}\text { APP1 My university's website has attractive interface } \\
\text { APP2 Elements in my university website are organized neatly } \\
\text { APP3 Content in my university's website is readable } \\
\text { APP5 My university's website can provide multimedia content attractively }\end{array}$ \\
\hline $\begin{array}{l}\text { User } \\
\text { Satisfaction } \\
\text { (SAT) }\end{array}$ & $\begin{array}{l}\text { SAT1. My university's website meets my expectation } \\
\text { SAT2. In general, my university's website has good quality } \\
\text { SAT3. In general, I'm happy with my university's website } \\
\text { SAT4. In general, I'm satisfied with performance of my university's website }\end{array}$ \\
\hline $\begin{array}{l}\text { Revisit } \\
\text { intention } \\
\text { (REV) }\end{array}$ & $\begin{array}{l}\text { REV1 I am going to revisit my university's website in the future } \\
\text { REV2 My university's website will be first website that I access when I } \\
\text { browse internet } \\
\text { REV3 I am going to invite my friends to visit my university's website }\end{array}$ \\
\hline $\begin{array}{l}\text { Attitude } \\
\text { toward the } \\
\text { brand } \\
\text { (ATT) }\end{array}$ & $\begin{array}{l}\text { ATT1 My university is an interesting university } \\
\text { ATT2 My university is a good university } \\
\text { ATT3 My university is a pleasant university } \\
\text { ATT4 My university has good quality }\end{array}$ \\
\hline $\begin{array}{l}\text { WOM } \\
\text { Intention } \\
\text { (WOM) }\end{array}$ & $\begin{array}{l}\text { WOM1 I always tell positive thing about my university to other people } \\
\text { WOM2 I always recommend my university to party that ask for my } \\
\quad \text { suggestion } \\
\text { WOM3 I always encourage my friends and family to choose my university } \\
\quad \text { as a place to study }\end{array}$ \\
\hline
\end{tabular}

Analysis in this research is modeled through Structural Equation Modeling. Structural Equation Modeling (SEM) is chosen as model and analysis tool in this research because of some reasons. First, SEM can examine the degree of compatibility in general or goodness of fit (GOF) between data and proposed model (Wijanto, 2008). Second, it can estimate relation between dependent variable, which is simultaneously related through structural model. Third, it can represent unobserved concept and do correction on measurement error (Hair et al., 2010). Fourth, SEM procedure can involve latent variable (unobserved) and observed (Byrne, 1998). To measure compatibility model, this research uses parameter such as Normed chi-square $\left(\chi^{2} / \mathrm{df}\right)$, root mean square error of 
approximation (RMSEA) and comparative fit index (CFI) as suggested by (Bagozzi \& Yi, 2011; Hair et al., 2010; Wijanto, 2008).

\section{Result and Discussion}

From online and offline data collection, there are 210 respondents with age 18-21 years old. Based on sex, $38 \%$ respondents are male meanwhile $62 \%$ are female. The data collection focuses on some university in JABODETABEK with quite good university's website such as Pelita Harapan University, Multimedia Nusantara University, University of Indonesia, Prasetya Mulya, Binus University, and Indonesia Banking School. According to profile of respondent, majority of respondent visit their campus website once to thrice a week.

According to estimation in model of measurement, it can be seen that standardized loading factor from all indicators are above 0.5 . In most model, 0.5 or above standardized loading factor score can be accepted to have good validity level (Wijanto, 2008). According to scores of standardized loading factor from result of model of measurement, we can count value of average variance extracted and composite reliability to score reliability degree of tool of measurement as explained on Table 2.

Table 2. Average Variance Extracted and Composite Reliability

\begin{tabular}{lcc}
\hline Construct & Composite reliability & AVE \\
\hline Motivation (MOT) & 0.794 & 0.562 \\
Ability (ABI) & 0.756 & 0.509 \\
Technical Quality (TEC) & 0.877 & 0.589 \\
Content Quality (CON) & 0.897 & 0.636 \\
Appereance Quality (APP) & 0.909 & 0.667 \\
User Satisfaction (SAT) & 0.924 & 0.753 \\
Revisit intention (REV) & 0.653 & 0.388 \\
Attitude toward the brand (ATT) & 0.895 & 0.680 \\
WOM Intention (WOM) & 0.989 & 0.745 \\
\hline
\end{tabular}

Sources: data processed

Based on the table, it can be concluded that overall ranking used in measuring research's construct is reliable.

Result of overall estimation model indicate that chi-square is 2.310 (good fit), RMSEA is 0.079 (good fit), and CFI is 0.887 (marginal fit). It can be inferred that overall research model has good compatibility model. Summary of hypothesis model based on collected sample data is presented on Table 3. 
Table 3. Hypothesis examination

\begin{tabular}{lccl}
\hline Stream & Coefficient & P-value & Conclusion \\
MOA $\rightarrow$ SAT & -0.101 & 0.034 & H1 not supported by data \\
WEQ $\rightarrow$ SAT & 1.025 & 0.000 & H2 supported by data \\
SAT $\rightarrow$ ATT & 0.746 & 0.000 & H3 supported by data \\
ATT $\rightarrow$ WOM & 1.082 & 0.000 & H4 supported by data \\
SAT $\rightarrow$ REV & 0.775 & 0.000 & H5 supported by data
\end{tabular}

Source: various data

From Table 3, it can be inferred that in general, except $\mathrm{H} 1$, the hypothesis is empirically proven according to collected data, which is indicated by above alpha, 0.05 , and positive coefficient, considering all hypothesis are positive. Examination result of $\mathrm{H} 2$ indicates that website quality is proven to give positive impact to degree of user satisfaction, in this case student's satisfaction towards university website as a service from university. Website quality in this context includes technical and navigation, and interface aspects. In other hand, $\mathrm{H} 1$ examination indicates that higher level of motivation and user ability will have impact on lower usage. Alternative explanation of this finding is that higher level of user's motivation and ability will have impact on higher user's expectation on one service's performance, in this case university's website. The implication, with assumption that level of service is constant, is that higher user's motivation and capability will have lower level of satisfaction.

Result of $\mathrm{H} 3$ examination indicates that higher level of user satisfaction will have impact on the higher level of attitude toward the brand in this case brand of student's university. It is not uncommon considering university's website, in general, is part of overall university's service, especially related to flow of information from university to the students or in some extraordinary case it is expanded to accommodate feedback facility from students to campus management. Furthermore, attitude toward the brand will push wordof-mouth-intention in higher level, as indicated in proved $\mathrm{H} 4$.

In other hand, user satisfaction toward campus' website will encourage user's intention to revisit. Proved H5 of this research indicated as such. Thus, user's satisfaction level will have two positive implications. At one side, user's satisfaction on campus website will eventually have positive implication in the creation of word-of-mouth intention. Meanwhile, level of satisfaction will have impact on higher user's intention to revisit the website. If the campus' website performance can be maintained and enhance, it will create continuous strengthening effect towards the formation of user's attitude intention towards formation of attitude intention towards campus' website as well as the campus itself. 
This research proves there is urgency for educational institution to have good website service. This urgency is a thing that can be comprehended considering education process in university is a long and complex process if it is compared to lower education level. It can be reflected by student's characteristic as service user has the higher level of capability and motivation to assess and demand acceptable quality of university's service. In this situation, campus website has role as direct and indirect communication tool, one way or two-way communication between students as users and university as service provider.

Regarding urgency of good campus website quality on university, this research underlines three aspects of website's quality. The first aspect is Technical Quality. In this aspect, management can emphasize the access speed and easy navigation as important element on Technical Quality performance. Access speed's performance can be maintained by providing adequate bandwidth in lane from and to storage server's system and content of campus website. Other efforts to maintain access speed is the use of light accessed website's elements such as emphasizing writing elements, compressed picture, not too big video. Meanwhile, easy navigation can be sought by the use of navigation layout or site map which is usually used by good website so that the user does not need to learn a lot about site map. Accurate and easy to use navigation system will add assessment that is more positive from user in terms of easy website's navigation and overall technical quality.

The second aspect on website quality is content quality. This aspect can be maintained by enriching campus website with various information especially useful and needed information for students as well as providing useful information for other users. Accuracy of information content must be maintained. It should not contain error or inaccuracy. It must also be delivered in clear and understandable way. Other important thing is renewal and frequent addition of content. The more frequent the content is added and renewed, the more interested the visitors are. The visitors might revisit with shorter interval.

The third aspect is Appearance Quality. Talking about appearance issue will be subjective depending on the way someone sees it. At least website admin can learn appearance such as what kind of appearance that is perceived well by the majority of the user at one time. It can be done in two ways, first is by investigating best practice at that time, and second is by doing a periodic survey on the users. In general, admin of website must provide neat, interesting appearance. 


\section{Managerial Implication}

This research underlines that there is urgency of good campus website implementation by university. The main emphasize is on its effort to maintain and enhance quality of campus website. The purposed quality includes three aspects that are technical quality, content quality, and appearance quality. Question about which aspect that needs to emphasize is out of this research's limitation, it opens opportunity to investigate other research or opportunity to have further specific research to examine importance degree of quality of service on campus website.

Finding about MOA construct toward user satisfaction that is opposite to initial hypothesis amplifies statement that there is urgency of campus website implementation by university management. In other hand, this finding also opens opportunity to possibility of further examination on MOA constructs as limit or as moderating factor in relations between website quality and user satisfaction. Further research is expected to explain more the role of motivation, opportunity, and ability aspects in creating user satisfaction especially in the context of campus website.

\section{Conclusion}

This research gives empirical proof that there is urgency of giving good campus website service by university. Website quality is empirically proven to give positive impact on creating user satisfaction especially students as object in this research. Higher user satisfaction will have two positive implications. In one side, user satisfaction is proven to increase level of attitude toward the brand, which eventually pushes word-of-mouth intention. Meanwhile, user satisfaction can provide positive implication in the form of higher intention to revisit. This condition enables the formation of strengthening cycle or weakening, it depends on high or low user satisfaction from time to time.

Different thing from initial hypothesis is that hypothesis about level motivation and ability level can increase user satisfaction was not proven. Empirical fact on this research indicates that higher motivation and ability will create negative impact in achieving user satisfaction. Explanation on this finding is that higher motivation and ability make user have high expectation in them when they do evaluation on service of campus website. The implication is it is getting more difficult to create user satisfaction. Satisfaction condition can be achieved if perception about service performance can exceed its initial expectations. This finding reflects statement that there is urgency for university to provide good campus website. 


\section{References}

Ajzen, I. (1991). The theory of planned behavior. Organizational Behavior and Human Decision Processes, 50(2), 179-211.

Ajzen, I., \& Fishbein, M. (1980). Understanding attitudes and predicting social behavior. EnglewoodCliffs NY Prentice Hall (Vol. 278). doi:Z

Al-Qeisi, K., Dennis, C., Alamanos, E., \& Jayawardhena, C. (2014). Website design quality and usage behavior: Unified Theory of Acceptance and Use of Technology. Journal of Business Research, 67(11), 2282-2290.

Bagozzi, R. P., \& Yi, Y. (2011). Specification, evaluation, and interpretation of structural equation models. Journal of the Academy of Marketing Science, 40(1), 8-34.

Baker, S. (2004). New Consumer Marketing: Managing a Living Demand System (Vol. 19). John Wiley \& Sons.

Brakus, J. J., Schmitt, B. H., \& Zarantonello, L. (2009). Brand Experience: What Is It? How Is It Measured? Does It Affect Loyalty? Journal of Marketing, 73(3), 52-68.

Brunner-Sperdin, A., Scholl-Grissemann, U. S., \& Stokburger-Sauer, N. E. (2014). The relevance of holistic website perception. How sense-making and exploration cues guide consumers' emotions and behaviors. Journal of Business Research, 67(12), 2515-2522.

Byrne, B. M. (1998). Structural Equation Modeling with LISREL, PRELIS and SIMPLIS: Basic Concepts, Applications and Programming. Mahwah, New Jersey: Lawrence Erlbaum Associates.

Cooper, D. R., \& Schindler, P. S. (2013). Business Research Methods (12th ed.). McGrawHill/Irwin.

Giese, J., \& Cote, J. (2000). Defining consumer satisfaction. Academy of Marketing Science Review, 1(1), 1-22.

Gruen, T. W., Osmonbekov, T., \& Czaplewski, A. J. (2007). Customer-to-customer exchange: Its MOA antecedents and its impact on value creation and loyalty. Journal of the Academy of Marketing Science, 35(4), 537-549.

Hair, J. F., Black, W. C., Babin, B. J., \& Anderson, R. E. (2010). Multivariate Data Analysis (7th ed.). Pearson Prentice Hall.

Hanzaee, K., \& Alinejad, S. (2012). Service Experience Influence on Generating Positive Word-of-mouth. Research Journal of Applied Sciences, 4(24), 5609-5616.

Hoyer, W. D., \& MacInnis, D. J. (2008). Consumer Behavior (5th ed.). South-Western: Cengage Learning.

Kim, H., \& Niehm, L. S. (2009). The Impact of Website Quality on Information Quality, Value, and Loyalty Intentions in Apparel Retailing. Journal of Interactive Marketing, 
23(3), 221-233.

Kuppelwieser, V. G., \& Sarstedt, M. (2014). Exploring the influence of customers' time horizon perspectives on the satisfaction-loyalty link. Journal of Business Research, 67(12), 2620-2627.

Maclnnis, D. J., \& Jaworski, B. J. (1989). Information Processing from Advertisements: Toward an Integrative Framework. Journal of Marketing, 53(4), 1-23.

Oliver, R. (1980). A cognitive model of the antecedents and consequences of satisfaction decisions. Journal of Marketing Research, 17(4), 460-469.

Oliver, R. (1999). Whence consumer loyalty? Journal of Marketing, 63, 33-44.

Pontevia, A. F. A., N'Goala, G., \& Poncin, I. (2013). A good deal online: The Impacts of acquisition and transaction value on E-satisfaction and E-loyalty. Journal of Retailing and Consumer Services, 20(5), 445-452.

Ryan, D., \& Jones, C. (2012). Understanding Digital Marketing: Marketing Strategies for Engaging the Digital Generation.

Selwyn, N. (2009). The digital native: myth and reality. Aslib Proceedings: New Information Perspective, 61(4), 364-379.

Spears, N., \& Singh, S. N. (2004). Measuring Attitude toward the Brand and Purchase Intentions. Journal of Current Issues \& Research in Advertising, 26(2), 53-66.

Wijanto, S. H. (2008). Structural Equation Modeling dengan LISREL 8.8: Konsep and Tutorial. Yogyakarta: Graha Ilmu.

Yadav, M. S., \& Varadarajan, R. (2005). Interactivity in the Electronic Marketplace: An Exposition of the Concept and Implications for Research. Journal of the Academy of Marketing Science, 33(4), 585-603.

Yoo, B., \& Donthu, N. (2001). Developing and validating a multidimensional consumerbased brand equity scale. Journal of Business Research, 52, 1-14.

Zikmund, W. G., Babin, B. J., Carr, J. C., \& Griffin, M. (2010). Business Research Methods (8th ed.). South-Western Cengage Learning. 